\title{
Infective Endocarditis Presenting as Polymyalgia Rheumatica: Case Report
}

\author{
Polimiyaljiya Romatikayı Taklit Eden İnfektif Endokardit: Olgu Sunumu \\ Cihat ÖZTÜRK, ${ }^{1}$ Selcen ÖZDEDELİ, ${ }^{1}$ Yasemin ÇINAR, ${ }^{1}$ Meral KAYIKÇIOĞLU' ${ }^{2}$ \\ ${ }^{1}$ Departments of Physical Medicine and Rehabilitation, Medical Faculty of Ege University, İzmir, Turkey \\ ${ }^{2}$ Departments of Cardiology, Medical Faculty of Ege University, İmir, Turkey
}

Infective endocarditis is a bacterial infection of the cardiac valves and endocardium with a high level of mortality and morbidity. Due to such high mortality and morbidity risks, early and accurate diagnosis bears great importance. Accordingly, for prevention of wrong or delayed diagnosis and treatment, it is important to know and be aware of diseases that can be mimicked by infective endocarditis and to keep such diseases in mind in the assessment and evaluation of the patient. In patients suffering from infective endocarditis, the disease may be accompanied by rheumatological symptoms and manifestations such as myalgia, arthralgia and arthritis. A review of the existing medical literature reveals a few cases of infective endocarditis mimicking polymyalgia rheumatica. In this article, we present a 64-year-old male case of infective endocarditis mimicking polymyalgia rheumatica without any known predisposing factor for infective endocarditis.

Key words: Echocardiography; infective endocarditis; polymyalgia rheumatica.

Infective endocarditis (IE) is a bacterial infection of the heart valves and endocardium. Bacterial endocarditis may present itself with rheumatological symptoms in $28-42 \%$ of patients. ${ }^{[1-3]}$ The most common musculoskeletal manifestation is myalgia, followed up arthralgia and peripheral arthritis, though this is seen more rarely. ${ }^{[3]}$ There are few cases of infective endocarditis mimicking polymyalgia rheumatica (PMR) reported in the literature.
Infektif endokardit, kalp kapakları ve endokardın mortalite ve morbidite seviyesi yüksek bir bakteriyel infeksiyonudur. Bu yüksek mortalite ve morbidite nedeniyle erken ve doğru tanı büyük önem taşımaktadır. Buna uygun şekilde, infektif endokarditin taklit edebileceği hastalıkların bilinmesi ve bunların farkında olunması ve hastanın değerlendirilmesi sırasında bu gibi hastalıkların akılda bulundurulması yanlış ya da gecikmiş tanı ve tedavinin önlenmesinde önemlidir. İnfektif endokarditten yakınan hastalarda hastalığa miyalji, artralji ve artrit gibi romatolojik semptomlar ve belirtiler eşlik edebilir. Mevcut tıbbi literatür incelendiğinde, polimiyaljiya romatikayı taklit eden çok az sayıda infektif endokardit olgusu bulunduğu görüldü. $\mathrm{Bu}$ yazıda, infektif endokardite eğilim yarattığı bilinen herhangi bir faktöre sahip olmayan ve polimiyaljiya romatikayı taklit eden infektif endokarditli 64 yaşında bir erkek hasta sunuldu.

Anahtar sözcükler: Ekokardiyografi; infektif endokardit; polimiyaljia romatika.

\section{CASE REPORT}

A 64-year-old man was admitted to our clinic with complaints of pain in his neck, shoulders and pelvis girdle. His symptoms had begun about two months previously and had become more intense and severe over time. The pains were reported to diminish with mobility, but no change was reported while resting. The pains were accompanied by morning stiffness 
which continued until afternoon. His systemic inquiry did not reveal any disease symptoms relating to his cardiopulmonary, gastrointestinal and genitourinary systems. The patient also hasn't suffered any trauma, arthralgia, arthritis, headache, mandibular claudication or visual problems recently.

About three months before admission to our clinic, the patient had intermittent fever episodes accompanied by a weight loss of $3 \mathrm{~kg}$ in three months. In the hospital where he went because of these complaints, he was diagnosed with Brucellosis and was, therefore, given an empiric antibiotic treatment. As a result, his fever episodes did not recur. The patient was on regular medication for hypertension and coronary artery disease.

In his physical examination, his body temperature was $37.2^{\circ} \mathrm{C}$, blood pressure was $120 / 80 \mathrm{mmHg}$ and pulse was $84 / \mathrm{min}$. The patient's cardio-respiratory system and abdominal examination showed no pathological finding. In his musculoskeletal examination, his neck and waist movements were painful and restricted in all directions due to pain. His pain was further accompanied by paravertebral muscle spasms. No sensitivity was detected with palpation of spinous processes. All upper and lower extremity joint movements were free of pain and restriction, including the shoulders and both hips. There also was no arthritis found. Test results for nerve stretching were negative. The patient had no neurological deficits.

In his laboratory examinations and tests, the patient had an erythrocyte sedimentation rate (ESR) of $69 \mathrm{~mm} / \mathrm{h}$ (Westergren method) and a C-reactive protein (CRP) level of $10.9 \mathrm{mg} / \mathrm{dl}$. His whole blood count demonstrated a hemogram value of $11.6 \mathrm{~g} / \mathrm{dl}$, a hematocrit value of $33.6 \%$ and a platelet count of $456.000 / \mathrm{mm}^{3}$. His blood chemistry was in the normal range in all liver and renal function tests, which also included alkaline phosphatase and creatine kinase. Protein electrophoresis was also in the normal range. No pathology was found in his urine test. His electrocardiogram (ECG) was considered normal. His serologic tests for brucella and salmonella were negative. The patient's PPD (purified protein derivative) was anergic. His tumor markers including prostate specific antigen were negative. Thyroid function tests (Free T3-T4 and TSH) were found to be in the normal range. His chest X-ray showed no pathologic abnormality. His cervical anteroposterior and lateral direct X-rays showed degenerative changes, and his lumbar anteroposterior and lateral X-rays showed loss of height in the first and second lumbar vertebral bodies.
His cervical and lumbar spinal magnetic resonance imaging (MRI) showed compression fractures of L1 and L2 vertebra without any edematous changes which prompted us to think that they were chronic fractures. In addition, the MRI detected diffuse spondyloarthrosis and spinal stenosis at multiple levels. His whole body scintigraphy showed an increased focal intake and retention of MDP in the right parietal cranium, lower thoracic and lumbar vertebral bodies and left knee. His cranium and knee X-rays taken to confirm this scintigraphic report did not reveal any pathological finding. In the patient's bone densitometry dual-emission X-ray absorptiometry (DXA, previously DEXA), bone mineral density values were found to be within normal ranges. When the patient's history was examined further, it was learned that he had fallen from a tree in the past, which explained the underlying cause of compression fractures.

The patient did not show any signs of cure or improvement upon medical and physical treatments where paracetamol, non-steroidal anti-inflammatory drugs, muscle relaxants, transcutaneous electrical stimulation or even tramadol were administered. In addition, his ESR and CRP also remained at elevated levels during follow-up.

Given that the patient was 64 years old, had an ESR of $>40 \mathrm{~mm} / \mathrm{h}$, and a morning stiffness lasting for more than one hour accompanied by pain in his neck, shoulders and pelvic girdles, and upon exclusion of other probable diagnosis, the patient was diagnosed with PMR. ${ }^{[4,5]}$ The patient was discussed in the joint council meeting of the Physical Therapy, Rheumatology and Orthopedics Departments of Faculty of Medicine of Aegean University. Upon PMR diagnosis, the patient began taking prednisolon at a dose of $16 \mathrm{mg} / \mathrm{day}$. On the second day of corticosteroid treatment, the patient was found to show only a low response to the corticotherapy. Also on the second day of treatment, as he had a fever $\left(38.5{ }^{\circ} \mathrm{C}\right)$, his urine and blood cultures were collected, and prednisolon treatment was ceased. His urine culture was negative, but all three blood cultures yielded Streptococcus viridans. The patient consulted with cardiology department and a preliminary diagnosis of infective endocarditis was given. There was no evidence or finding of infective endocarditis in his echocardiography, but transesophageal echocardiography (TEE) showed vegetations evoking the diagnosis of infective endocarditis. Therefore, the patient was diagnosed with infective bacterial endocarditis as two main criteria (positive blood cultures and TEE findings) 
and one sub-criterion (body temperature above $38^{\circ} \mathrm{C}$ ) were met according to Duke's diagnosis criteria. ${ }^{[4,6,7]}$ Thereupon, the patient was began treatment with gentamicin (240 mg/day) and penicillin (24 million units daily), and the patient was transferred to the Cardiology Intensive Care Department where he underwent an aortic valve replacement surgery for aortic insufficiency. During the postoperative period, no complication was observed, and all symptoms of the disease, including musculoskeletal system, were totally resolved with treatment.

\section{DISCUSSION}

Infective endocarditis is predominantly seen in patients with cardiac valve lesions or in cases of drug addiction. However, González-Juanatey et al. ${ }^{[3]}$ reported that $26 \%$ of IE cases do not in fact have a previous known cardiac problem or drug addiction history as in our case. Although these cases are few in the literature, IE cases mimicking PMR were all reported to have a known risk factor for IE. On the other hand, if and when the patient demonstrates no evidence or finding of any diagnostic criteria at the time of admission to the hospital, it becomes extremely difficult to make an accurate and early diagnosis of IE.

Rheumatic signs and manifestations of infective endocarditis were reported in some series of cases. ${ }^{[1-3]}$ Infective endocarditis is reported to have a wide range of musculoskeletal symptoms varying from myalgia to PMR. ${ }^{[1-3]}$ But mimicking of PMR by infective endocarditis is a very rare condition; for instance, it was reported as one in 110 patients in a series of studies published by González-Juanatey et al. ${ }^{[3]}$ In a nationwide French study of giant cell arteritis conducted on 400 patients, a case of initially misdiagnosed infective endocarditis is mentioned. ${ }^{[8]}$ In a literature scan through the Medline search motor, we could find only a few case reports related to this topic. ${ }^{[3,9-12]}$

Auzary et al. ${ }^{[10]}$ reported three cases comprised of one case of infective endocarditis mimicking isolated PMR and two cases of polymyalgia rheumatica associated with giant cell arteritis. In contrast to the case reported by us in this article, all such reported cases had a previously known valvular disease. Gretillat et al. ${ }^{[12]}$ reported a case of IE with cervical and lumbar pain complaints without fever and elevated ESR levels. This case is similar to ours except for the ESR levels. González-Gay et al. ${ }^{[11]}$ reported and presented a case of IE mimicking PMN resistant to corticosteroid treatment. These authors reported "unexplained fever and lack of response to prednisone treatment" as the data suggesting the presence of a condition different from isolated PMR. Furthermore, minimal morning stiffness, visceral enlargement and unexplained hematuria should also alert the clinician as signs of IE. ${ }^{[1]}$ González-Gay et al. ${ }^{[1]}$ also reported that atypical symptoms of PMR and, in addition, fever with or without cardiac murmur must further be considered as signs and evidences of a suspicious IE case. Also, response to corticosteroids can be used to support the diagnosis of PMR. ${ }^{[1]}$ The "absence of recovery or improvement after seven days of corticosteroid treatment" can be a clue for any underlying disease, primarily giant cell arteritis. ${ }^{[11]}$ However, our patient did not have either a fever or cardiac murmur at the time of admission to the hospital, and fever developed in the second day of corticosteroid treatment with an accurate diagnosis coming later. Supporting that, González-Gay et al. ${ }^{[1]}$ emphasized that in cases accompanied by musculoskeletal symptoms, low body temperature and lack of symptoms evoking the diagnosis of IE are good and just reasons for exclusion of IE probability.

González-Juanatey et al. ${ }^{[3]}$ emphasized that rheumatic manifestations in patients with IE from Western countries are more common in men in their late 40 s or 50s, while in Africa and the Middle East these manifestations are reported primarily in the young population, predominantly in men, and in patients from rural areas. These authors further reported that microhematuria and lower serum complement levels are more common in IE patients with rheumatic complications. All of these findings were thought to be caused by an immune complex-mediated process initiated by antigen products of the infectious agent responsible for IE or by abnormal immunoregulation associated with the infectious disease. ${ }^{[3]}$ However, even these processes are only general propositions relating to rheumatic manifestations and symptoms of IE; for instance, hematuria was not found in our patient though he matched the above cited propositions by his gender, age and rural living area. Regarding microbiologic etiology, almost all of the reported cases of IE mimicking PMR included probable bacterial causes of IE. ${ }^{[10,11]}$ In the medical literature, it is reported that in most of the cases, the symptoms of PMR dramatically respond to antibacterial treatment as in our case. ${ }^{[10,11]}$ Although septic embolism was reported more commonly in rheumatic manifestations of IE, they do not result in any significant increase in cardiac complications or outcome. ${ }^{[3]}$ 
Polymyalgia rheumatica is a condition in which the diagnosis mostly relies upon the exclusion of other probabilities. Accordingly, the physician should continue to be suspicious of other probable diseases mimicking PMR, even after making the diagnosis of PMR and starting treatment in reliance thereupon. The only clue of other underlying diseases may be resistance of the patient to corticosteroid treatment. That is why the patients showing rheumatic symptoms with or without valvular heart disease should always alert us to keep in mind the case of an underlying IE. As we all know, IE is a serious disease with high morbidity and mortality where early and accurate diagnosis plays an important role in prognosis. Therefore, rheumatic conditions requiring corticosteroid treatment such as PMR should be treated only after the probability of IE has been completely ruled out.

\section{Declaration of conflicting interests}

The authors declared no conflicts of interest with respect to the authorship and/or publication of this article.

\section{Funding}

The authors received no financial support for the research and/or authorship of this article.

\section{REFERENCES}

1. Thomas P, Allal J, Bontoux D, Rossi F, Poupet JY, Petitalot JP, et al. Rheumatological manifestations of infective endocarditis. Ann Rheum Dis 1984;43:716-20.

2. Meyers OL, Commerford PJ. Musculoskeletal manifestations of bacterial endocarditis. Ann Rheum Dis 1977;36:517-19.
3. González-Juanatey C, González-Gay MA, Llorca J, Crespo F, García-Porrúa C, Corredoira J, et al. Rheumatic manifestations of infective endocarditis in non-addicts. A 12-year study. Medicine (Baltimore) 2001;80:9-19.

4. Bird HA, Esselinckx W, Dixon AS, Mowat AG, Wood PH. An evaluation of criteria for polymyalgia rheumatica. Ann Rheum Dis 1979;38:434-9.

5. Bird HA, Leeb BF, Montecucco CM, Misiuniene N, Nesher G, Pai S, et al. A comparison of the sensitivity of diagnostic criteria for polymyalgia rheumatica. Ann Rheum Dis 2005;64:626-9.

6. Durack DT, Lukes AS, Bright DK. New criteria for diagnosis of infective endocarditis: utilization of specific echocardiographic findings. Duke Endocarditis Service. Am J Med 1994;96:200-9.

7. Bayer AS. Revised diagnostic criteria for infective endocarditis. Cardiol Clin 1996;14:345-50.

8. Duhaut $\mathrm{P}$, Pinede L, Demolombe-Rague $\mathrm{S}$, Loire R, Seydoux D, Ninet J, et al. Giant cell arteritis and cardiovascular risk factors: a multicenter, prospective case-control study. Groupe de Recherche sur l'Artérite à Cellules Géantes. Arthritis Rheum 1998;41:1960-5.

9. Spomer A, Ho G Jr. Bacterial endocarditis and septic arthritis presenting as polymyalgia rheumatica. R I Med 1994;77:5-6.

10. Auzary C, Le Thi Huong D, Delarbre X, Sbai A, Lhote F, Papo T, et al. Subacute bacterial endocarditis presenting as polymyalgia rheumatica or giant cell arteritis. Clin Exp Rheumatol 2006;24:S38-40.

11. González-Gay MA, García-Porrúa C, Salvarani C, Olivieri I, Hunder GG. Polymyalgia manifestations in different conditions mimicking polymyalgia rheumatica. Clin Exp Rheumatol 2000;18:755-9.

12. Gretillat F, Debievre J, Lubetzki J. Letter: Bacterial endocarditis revealed by rhizomelic pseudopolyarthritis. Nouv Presse Med 1976;5:1534. [Abstract] 